\title{
Study on Influence Mechanism of Leader-member Exchange Differences to Team Performance
}

\author{
Mengchao Liu \\ School of Management \\ Wuhan University of Technology \\ Wuhan, China
}

\begin{abstract}
In the information explosion in twenty-first Century, enterprises are facing increasingly fierce competitions, the job content becomes more complex, so teams play a more prominent role in company. The purpose of this article is to study the effect of leader-member exchange on team performance, and the mediating role of team atmosphere. This research adopted the mature scales through the questionnaire in companies and universities in Hubei. The article confirmed that LMX makes positive influence on team performance, and partly intermediary function of team atmosphere. This article expands the research field of Leadermember Exchange theory and enriches the research model of team performance.
\end{abstract}

Keywords-leader-member exchange; team performance; team atmosphere

\section{INTRODUCTION}

Graen(1975)proposed the Leader-Member Exchange (LMX) theory. The theory has raised the awareness that there is a difference in how a leader treats subordinates in a team. At present, most of the researches on the theory of leadership exchange are focused on the individual level (Dechurch, 2010), neglecting the influence of team members' exchange differences on team results. In a team, due to the resources, time constraints, the exchange relationships between team leader and team members are quite different (Li, 2013). At this point, the team members will have a different perception of leader member exchange, which due to different work behavior and attitude, thus affecting team performance. Therefore, it is of great theoretical significance to study the team performance based on the difference of leader member exchange. In practice, this have significant practical value on enhancing the overall performance of enterprises.

From the theory of leader member exchange be proposed, the theory has been paid more and more attention by domestic and foreign scholars. Previous studies on the leader-member exchange and performance focused on individual performance. With the popularity of team work in modern enterprises, scholars began to integrate lead-member exchange with team work. Boies (2006) and other studies have shown that the quality of leader-members exchange can reduce team conflict and improve team effectiveness. Team members, which have high quality exchange with team leader, can get more attention and trust from team leader as well as more rewards and promotion opportunities. Therefore, these employees will be based on the principle of social exchange feedback, in addition to personal performance improvement, this feedback also includes contribution to team work, and then improve team performance (Martin, 2010). The high quality of leader member exchange leads to an atmosphere of mutual respect and cooperation. Good team atmosphere and team interaction on the positive role of team performance has also been generally confirmed. But for those who do not maintain a high-quality exchange with the leaders, leaders' differential treatment will make them feel unfair, which could result in team conflict, reduce the cohesion of team members, and have a negative impact on team performance(Liu, Zhang and Zhong, 2009).

However, these studies only show the effect of the quality of leader-member exchange on individual and team performance, not the influence of the difference of leadermember exchange on team performance. In recent years, the different relationship in leader-member exchange has become a hot issue (Wang and Zhong, 2011). Team leader and members have differences in exchange quality, which called lead member exchange differences (Erdogan and Bauer, 2010). The quality of the exchange usually coexist in a team. Employees perceive the difference in the exchange relationship between others and leader also affects their work attitude and behavior. As to the influence of the difference of leader member exchange on team performance, early researchers generally agreed that the existence of differences on the team is harmful. Research has shown that differences can reduce team effectiveness and increase team conflict. Schyns 'research suggests that differences may reduce team members' job satisfaction. As the research progresses, scholars have found that differences in relationships do not always have a negative impact. Liden (2006) found that in a team with a low level of leader exchange, relationship difference can improve team performance to a certain extent. In the latter part of the team work, leader treats team members differently can improve team performance (Wang and Zhong, 2011). In addition, Erdogan and Bauer (2010) found that when the team fair atmosphere is high, the motivation of the team members is not affected by the difference of the relationship. Chinese scholars (Zhao and 
Song, 2010) also show that the relationship differences does not always have a negative impact on team effectiveness.

\section{HYPOTHESES}

\section{A. Team Atmosphere and Team Performance}

Team members' perceptions of specific contexts form a team atmosphere. It can affect members' attitudes, behaviors and values (Liu, Xie and Meng, 2011). When the team members feel good about the team atmosphere, their job satisfaction and work efficiency will increase (Xie, 2012). Team innovation atmosphere, service atmosphere, fair atmosphere all have an impact on team performance. Mutual trust between team members can increase the cooperation between members as well as enable them to understand each other's strengths and weaknesses. This avoids unfamiliarity between members which could result in inefficiencies. In a trusty team atmosphere, the interpersonal relationship between team members is good, which enable them to have in-depth communication and due to high team performance. Improving team members' sense of participation can improve team communication efficiency, which is conducive to creating a positive team atmosphere. This is the driving force for team members to work hard to improve their performance (Zhang, 2014). In a good atmosphere of communication team, the contradictions and misunderstandings can be handled well, and team members have mutual recognition. This contributes to a sense of belonging among the members, which drives performance. For the cross-cultural team, a good communication atmosphere can solve the misunderstanding caused by different cultures, contribute to the establishment of mutual trust and a fair atmosphere, and improve team innovation performance. Fair team atmosphere will also affect performance. Lester's (2002) study confirmed that when a team has a fair atmosphere, team members feel that they have been treated fairly and that the efforts they make are positive. This can reduce the team members of the psychological gap, enhance their team identity, and finally improve performance. The atmosphere of adventure and cooperation can positively affect the team's knowledge integration. This is especially true for high-tech teams, which can accelerate the development of new products and play a positive role in team innovation performance (Baer, 2012). Therefore, we propose the following hypothesis:

H1: Team atmosphere has a positive impact on team performance.

\section{B. Leader-member Exchange and Team Atmosphere}

Leaders and team members in order to complete the team goals, work together, the two sides through the exchange of interaction, forming team atmosphere. But in this process, the leader and the team members formed different exchange relationship, so members feel the team atmosphere will be different. In the high-quality exchange of leadership members, team members are given greater decision-making and feel a higher sense of trust. They feel the leader's love and support, and will be more willing to make excessive efforts to team goals. Members will enhance the exchange of information and mutual assistance, which will to some extent to promote the team atmosphere of trust and innovation atmosphere (Sun, 2009). Differences in the exchange relationship will make team members fell differential treatment from team leader. For members have good relations with team leader, they want to continue to maintain their competitive advantage in the team. While those who are more distant from the leader are trying to narrow the gap with leadership by hard work. So leading members of the exchange of differences will enhance the team competitive atmosphere. To sum up, we propose the following hypothesis:

H2: Leader-member exchange differences have a positive impact on the team atmosphere.

\section{The Intermediary Role of Team Atmosphere}

Leadership is an important factor affecting the team atmosphere, team leaders play an important role in fostering a positive work ethic. Leader treats subordinates differently because of their own personality traits, Subordinate personality characteristics, and their ability. Some employees in the work can get trust and support from leader, and frequent exchanges of leadership. They will naturally come back through hard work leadership for their support and help, pay extra effort for team performance and pay or even do outside the scope of the work. Such employees are aware of a positive team atmosphere, harmonious relationship with the leadership, so they have high job satisfaction as well as high job performance (Dulebohn, Bommer, Liden et al. 2012). On the contrary, for members have low exchange quality, they are less concerned about the leadership and support, low sense of belonging to the team and poor work motivation, which could reduce work performance. The differences in the exchange of leadership members affects the fair atmosphere of the team. Obviously, for employees in low-quality exchange relationships, they are less likely to feel team equity. This will aggravate the formation of team conflicts, and have negative impact on team performance (Harris, Li and Kirkman, 2014). On the other hand, differences in exchange will enhance the team's competitive atmosphere. For "in-the-box" employees, they want to have existing resources continuously and maintain existing strengths, so they will work harder to improve performance. While for "out-of-the-box" employees, they realize that they can get leader's attention by improving their performance and become "in-the-box" members. This relationship difference can improve their performance. It can be seen that the differences in exchange affect the team interaction, which also relates to the team atmosphere. Therefore, we propose the following hypothesis:

H3: The team atmosphere plays an intermediary role in the positive effect of the leader member exchange differences on team performance. 


\section{METHODS}

\section{A. Variable Design}

1) Independent variable (LMX): This study refers to Wang Hui revised LMX four-dimensional scale. "Table I" The scale is based on Liden and Maslyn (1998) LMX fourdimensional scale, combined with Chinese culture to amend. We select emotion, loyalty and contribution to measure leader-member exchange.

TABLE I. LEAD MEMber Exchange MeAsurement Scale

\begin{tabular}{|c|c|c|}
\hline NO. & Dimensions & Items \\
\hline LMX1 & \multirow{3}{*}{ Emotion } & I really like the person I am in charge of. \\
\hline LMX2 & & It's interesting to work with my supervisor. \\
\hline LMX3 & & $\begin{array}{l}\text { I would like to associate with my } \\
\text { supervisor and work together. }\end{array}$ \\
\hline LMX4 & \multirow{3}{*}{ Loyalty } & $\begin{array}{l}\text { My leader would defend my work behavior } \\
\text { in front of his/her superior, even if he/she } \\
\text { doesn't know enough about it. }\end{array}$ \\
\hline LMX5 & & $\begin{array}{l}\text { My supervisor will defend me in front of } \\
\text { other people if I made a mistake. }\end{array}$ \\
\hline LMX6 & & $\begin{array}{l}\text { My supervisor will be on my side, when I } \\
\text { conflict with others. }\end{array}$ \\
\hline LMX7 & \multirow{3}{*}{ Devotion } & $\begin{array}{l}\text { I' } m \text { willing to pay extra effort for the } \\
\text { benefit of my supervisor. }\end{array}$ \\
\hline LMX8 & & $\begin{array}{l}\text { I would like to do more work than I do for } \\
\text { my supervisor. }\end{array}$ \\
\hline LMX9 & & $\begin{array}{l}\text { In order to my supervisor, I will try my } \\
\text { best to do my own job, and even out of the } \\
\text { job. }\end{array}$ \\
\hline
\end{tabular}

2) Dependent variable: We use the scale prepared by Van Scotter (1996), and reference to Huang Qing's Chinese translation to measure team performance. The scale measures team performance from three aspects: task achievement, member satisfaction and team survival. "Table II"

TABLE II. Team PERformance Measurement ScAle

\begin{tabular}{|c|c|c|}
\hline NO. & Dimensions & Items \\
\hline TP1 & \multirow{4}{*}{$\begin{array}{l}\text { Task } \\
\text { achievement }\end{array}$} & $\begin{array}{l}\text { Team members are aware of the } \\
\text { mission objectives and can accomplish } \\
\text { the task within the planned time. }\end{array}$ \\
\hline TP2 & & $\begin{array}{l}\text { Team members work very hard and } \\
\text { have high work efficiency. }\end{array}$ \\
\hline TP3 & & $\begin{array}{l}\text { Team members have the ability to adapt } \\
\text { to different jobs. }\end{array}$ \\
\hline TP4 & & $\begin{array}{l}\text { Team members work together and share } \\
\text { their joys and sorrows. }\end{array}$ \\
\hline TP5 & \multirow{3}{*}{$\begin{array}{l}\text { Member } \\
\text { satisfaction }\end{array}$} & $\begin{array}{l}\text { Team members are satisfied with their } \\
\text { performance at work. }\end{array}$ \\
\hline TP6 & & $\begin{array}{l}\text { Team members are satisfied with the } \\
\text { results of the work of the team. }\end{array}$ \\
\hline TP7 & & $\begin{array}{l}\text { Team members are satisfied with the } \\
\text { work style. }\end{array}$ \\
\hline TP8 & \multirow{4}{*}{$\begin{array}{l}\text { Team } \\
\text { survival }\end{array}$} & $\begin{array}{l}\text { Team members can learn something } \\
\text { useful when they work together. }\end{array}$ \\
\hline TP9 & & $\begin{array}{l}\text { Team members have a strong } \\
\text { willingness to learn. }\end{array}$ \\
\hline TP10 & & $\begin{array}{l}\text { Team members are encouraged when } \\
\text { they are in trouble. }\end{array}$ \\
\hline TP11 & & $\begin{array}{l}\text { Team members are able to accept new } \\
\text { things. }\end{array}$ \\
\hline
\end{tabular}

3) Mediator variable: This article according to Sun and Liu's research (2008), using team trust and team openness to measure team atmosphere. The team trust dimension also refers to the trust scale developed by Rauniar (2005). "Table III"

TABLE III. TEAM ATMOSPHERE MEASUREMENT SCALE

\begin{tabular}{|c|l|l|}
\hline NO. & $\begin{array}{c}\text { Dimension } \\
\text { s }\end{array}$ & \multicolumn{1}{|c|}{ Items } \\
\hline \multirow{2}{*}{ TA1 } & \multirow{5}{*}{ Team trust } & $\begin{array}{l}\text { Team members fully trust each other and } \\
\text { are willing to share all relevant } \\
\text { information. }\end{array}$ \\
TA2 & $\begin{array}{l}\text { Team members are convinced that they } \\
\text { can be trusted. }\end{array}$ \\
TA3 & $\begin{array}{l}\text { Team members agree that all members are } \\
\text { honest. }\end{array}$ \\
TA4 & $\begin{array}{l}\text { Team members believe that the } \\
\text { information provided by others is true. }\end{array}$ \\
\hline \multirow{2}{*}{ TA5 } & \multirow{2}{*}{$\begin{array}{l}\text { Team } \\
\text { openness }\end{array}$} & $\begin{array}{l}\text { The different opinions of team members } \\
\text { can be taken seriously. }\end{array}$ \\
TA6 & $\begin{array}{l}\text { Team members agreed that the quality of } \\
\text { decision-making will improve when } \\
\text { everyone participate in the discussion. }\end{array}$ \\
\hline
\end{tabular}

\section{B. Data Collection}

This research takes the team leader and team members of the enterprise team (including the marketing team, R \& D team, etc.), the college student organizations, the students' unions as the research object. We choose 28 teams randomly in Hubei Province to hand out questionnaires. A total of 360 questionnaires were sent out, and 346 questionnaires were collected including 332 valid questionnaires. The recovery rate and effective rate were $96.1 \%$ and $92.2 \%$ respectively.

\section{RESULTS}

\section{A. Reliability}

We use SPSS19.0 to analyze the reliability of each variable. We found that the total Cronbach was 0.951, and single variable-LMX(leader member exchange), TP(team performance), TA(team atmosphere) Cronbach was 0.887, $0.941,0.844$ respectively. That shows the reliability of the data is reliable. "Table IV"

TABLE IV. RELIABILITY STATISTICS

\begin{tabular}{|l|l|l|}
\hline & Cronbach's Alpha & \multicolumn{1}{|c|}{ N } \\
\hline All variable & .951 & 26 \\
\hline LMX & .887 & 9 \\
\hline Team performance & .941 & 11 \\
\hline Team atmosphere & .844 & 6 \\
\hline
\end{tabular}

We also discussed the correlation coefficients of each variable. We can find in "Table V" that the correlations between variables LMX, TP and TA are all significant. While the correlations between the four control variables, age, educational level, working time in the team and team size, are not significant. 
TABLE V. CORRELATION MATRIX

\begin{tabular}{|c|c|c|c|c|c|c|c|}
\hline & Age & $\begin{array}{c}\text { Degr } \\
\text { ee }\end{array}$ & Time & Scale & $\begin{array}{c}\mathbf{L M} \\
\mathbf{X}\end{array}$ & $\mathbf{T P}$ & $\begin{array}{l}\text { T } \\
\mathbf{A}\end{array}$ \\
\hline Age & 1 & & & & & & \\
\hline Degree & .074 & 1 & & & & & \\
\hline Time & .003 & -.109 & 1 & & & & \\
\hline Scale & -.025 & -.112 & $.157^{*}$ & 1 & & & \\
\hline LMX & $-.159 *$ & -.054 & $\begin{array}{l}.088 \\
\end{array}$ & .076 & 1 & & \\
\hline $\mathrm{TP}$ & $\begin{array}{l}- \\
.212 * \\
*\end{array}$ & -.116 & -.015 & .122 & $\begin{array}{l}.706 \\
* *\end{array}$ & 1 & \\
\hline TA & -.142 & -.003 & -.139 & .113 & $\begin{array}{l}.568 \\
* *\end{array}$ & $.697 * *$ & 1 \\
\hline
\end{tabular}

\section{B. Confirmatory Factor Analysis}

We use SPSS19.0 to confirmatory factor analysis for each variable. The academic community generally agreed that to make the factor analysis valid, the sample size is at least 5 times the observed variable. When the sample size is more than 10 times of the observed variable, the factor validity analysis is more ideal. The sample size of this survey is 354 , the number of observable variables is 26 , and the number of samples is 14 times of the variables, which meets the requirements. KMO (Kaiser-Meyer-Olkin) and Bartlett ball tests were performed prior to confirmatory factor analysis, as shown in "Table VI".

TABLE VI. KMO AND BARTLETT BALL TEST

\begin{tabular}{|l|l|}
\hline Kaiser-Meyer-Olkin & .928 \\
\hline Bartlett ball test approximate chi square & 2903.658 \\
\hline df & 325 \\
\hline sig & .000 \\
\hline
\end{tabular}

KMO value is proportional to the suitability of factor analysis. In other words, the greater the KMO value, the more effective factor analysis. In this study, the KMO value reached 0.928 , indicating that the observed values are suitable for factor analysis. The exploratory factor analysis of this study was carried out by principal component analysis (PAC) in SPSS19.0 and variance maximum orthogonal rotation. According to factor load factor for each item to choose, the various factors classified as three categories. "Table VII"
TABLE VII_ ROTATION COMPONENT MATRIX

\begin{tabular}{|l|l|l|l|}
\hline \multirow{2}{*}{} & \multicolumn{3}{|c|}{ component } \\
\cline { 2 - 4 } & \multicolumn{1}{|c|}{$\mathbf{2}$} & \multicolumn{1}{c|}{$\mathbf{3}$} \\
\hline TP4 & .754 & .228 & .266 \\
\hline TP6 & .733 & .193 & .270 \\
\hline TP5 & .727 & .201 & .168 \\
\hline TP3 & .726 & .240 & .271 \\
\hline TP2 & .712 & .287 & .253 \\
\hline TP8 & .712 & .271 & .250 \\
\hline TP11 & .662 & .290 & .317 \\
\hline TP1 & .661 & .296 & .264 \\
\hline TP7 & .655 & .195 & .374 \\
\hline TP10 & .651 & .260 & .338 \\
\hline TP9 & .622 & .157 & .326 \\
\hline LMX6 & .077 & .766 & .277 \\
\hline LMX5 & .250 & .721 & .150 \\
\hline LMX7 & .194 & .718 & .323 \\
\hline LMX3 & .529 & .616 & -.031 \\
\hline LMX2 & .548 & .608 & -.089 \\
\hline LMX4 & .335 & .596 & .174 \\
\hline LMX1 & .510 & .580 & -.069 \\
\hline LMX9 & .304 & .558 & .234 \\
\hline LMX8 & -.004 & .545 & .509 \\
\hline TA2 & .122 & .098 & .787 \\
\hline TA4 & .344 & .133 & .630 \\
\hline TA1 & .357 & .140 & .583 \\
\hline TA6 & .328 & .248 & .575 \\
\hline TA3 & .456 & .078 & .575 \\
\hline TA5 & .384 & .311 & .564 \\
\hline & & & \\
\hline
\end{tabular}

\section{Mediating Role Model}

TABLE VIII. MEDIATION FUNCTION REgRESSION ANALYSIS

\begin{tabular}{|c|c|c|c|c|}
\hline \multirow{2}{*}{ Variables } & (1) & (2) & (3) & (4) \\
\hline & $J X$ & $J X$ & $F W$ & $J X$ \\
\hline Age & -.047 & -.116 & .045 & -.068 \\
\hline Degree & -.072 & -.114 & .030 & -.086 \\
\hline Time & .042 & .098 & -.112 & .093 \\
\hline Scale & .052 & .009 & .094 & .010 \\
\hline LMX & $.695^{* * * *}$ & & $.559^{* * * *}$ & $.442 * * *$ \\
\hline FW & & $701 * * *$ & & $.452 * * *$ \\
\hline R2 & .511 & .516 & .341 & .633 \\
\hline$\triangle \mathrm{R} 2$ & .511 & .516 & .341 & .646 \\
\hline $\mathrm{F}$ & $\begin{array}{l}33.432 * \\
* *\end{array}$ & $34.130 * * *$ & $\begin{array}{l}16.541 * * \\
*\end{array}$ & $\begin{array}{l}48.334 * * \\
*\end{array}$ \\
\hline
\end{tabular}

\section{CONCLUSION}

In the team, the leaders should try to maintain good relations with each member, and provide guidance and help for their work. A high-quality leader member exchange enhances team performance by enhancing communication efficiency and information exchange. For employees have high-quality leader member exchange, they get more attention and work support from the leaders, the enthusiasm of the work will be higher. Leaders will give these employees a higher rating as well as more support for their work.

Leaders in the usual work should pay attention to create a good team atmosphere. A positive team atmosphere can influence the team members' work attitude and work behavior, finally affecting the work performance of the entire team. A good team atmosphere can enhance team cohesion and information exchange between team members. Effective 
communication can eliminate the contradictions and friction between team members. Fair, trust team atmosphere could motivate team members to work enthusiasm and creativity, and make the team full of energy.

Leaders should encourage team members to enhance communication and collaboration. Interacting with team members can reduce work pressure, activate team atmosphere, and make it easier to reach consensus when opinions are inconsistent. The establishment of the team collaboration mechanism can reduce the burden on the management of leaders, and improve team members' selfmanagement ability. Leaders give the team members full trust can enable employees to feel leaders' affirmation and attention, which can effectively encourage them to accept more challenging tasks and make efforts to complete. Not only can improve personal performance, the performance of the entire team will be a corresponding increase.

\section{REFERENCES}

[1] Baer, M. (2012) 'Putting creativity to work: The implementation of creative ideas in organizations',

[2] Academy of Management Journal, 55(5), pp.1102-1119.

[3] Dechurch L.A., Hiller H.J., Murase T., et al. (2010) 'Leadership across Levels:Lexels of Leaders and Their Levels of Impact', Leadership Quarterly, 21(6), pp.1069-1085.

[4] Dulebohn, J.H., Bommer, W.H., Liden, R.C. et al. (2012) 'A mateanalysis of antecedents and consequences of leader-member exchange: Integrating the past with an eye toward the future', Journal of Management, 38(6), pp.1715-1759.

[5] Erdogan, B. and Bauer, T.N. (2010) 'Differentiated leader-member exchange: The buffering role of justice climate', Journal of Applied Psychology, 95, pp.1104-1120.

[6] Harris, T.B., Li, N. and Kirkman, B.L. (2014) 'Leader-member exchange (LMX) in context: How LMX differentiation and LMX relational separation attenuate LMX's influence on OCB and turnover intention', The Leadership Quarterly, 25, pp.314-328.

[7] Liu, B., Xie, F.T. and Meng, Q.C. (2011) 'An Empirical Analysis of the Effect of Team Climate on Team Performance', China Soft Science, (11), pp.133-140.

[8] Liu, J., Zhang, K., Zhong, L.F. (2009) 'The Formation and Influence of Work Team 's Disorder: An Empirical Analysis Based on Tracing Data', Management World, (8), pp.92-101

[9] Li, Y.Y. (2013) 'A Study on the Effect Mechanism of Leadermember Exchange on Team learning-Interactive Fair as the Intermediary', Liaoning: Dalian University of Technology.

[10] Martin R., Epitropaki O., Thomas G.,et al. (2010) A Review of Leader-Member Exchange Research: Future Prospects and Directions, Chichester:Wiley.

[11] Sun, R., Shi, J.T. and Zhang, T.Q. (2009) 'An Empirical Study on the Relationship among Corporate Leadership Member Exchange, Team Member Exchange, Organizational Innovation Climate and Employee Innovation Behavior', Journal of Industrial Engineering and Engineering, 23(4), pp.109-114.

[12] Wang, Z., Zhong, L. (2011) 'A Review and Prospect of Leadermember Exchange Relation Differentiation', Advances in Psychological Science, 19(7), pp.1037-1046.

[13] Xie, F.T. (2012) 'The Relationship between Team Climate and Team Effectiveness-Team Conflict as the Mediator Variable', Shandong: Shandong University.

[14] Zhang, X.E., Sun, Z.B., Wei, T. (2014) 'How Entrepreneurial Team Heterogeneity Affects Performance: Analysis of Mediator Effect Based on Team', Journal of Wuhan University(Philosophy \& Social Sciences), (3), pp.106-111.
[15] Zhao, G.X. and Song, W.F. (2010) 'The Relationship between Leader-member Exchange Relation, Equity and Cohesion', Psychological Science, 22(2), pp.271-281. 